\title{
Multiple Myeloma and Change of ABO Blood Group Type: A Case Report
}

\author{
Madeeha Subhan Waleed $^{1}$, Waleed Sadiq ${ }^{2}$ \\ 1. Internal Medicine, Ayub Teaching Hospital, Islamabad, PAK 2. Internal Medicine, Staten Island University Hospital, \\ New York, USA
}

Corresponding author: Madeeha Subhan Waleed, madeehas99@gmail.com

\begin{abstract}
Multiple myeloma is a hematopoietic stem cell malignancy that involves the plasma cells. It starts insidiously and usually involves males in their 60's. Clinical manifestations usually include anemia, kidney disease, hypercalcemia, and bone pains. We present a male with multiple myeloma whose blood group changed from $\mathrm{AB}$ positive to $\mathrm{O}$ positive. $\mathrm{ABO}$ blood group change can occur in multiple myeloma so blood group should be checked thoroughly in patients with hematological malignancies to prevent serious hematological reactions.
\end{abstract}

Categories: Internal Medicine, Pathology, Oncology

Keywords: tumor, hematology, hypercalcemia, multiple myeloma, malignancy, blood group

\section{Introduction}

Multiple myeloma is a hematopoietic stem cell malignancy that involves the plasma cells. It starts insidiously and usually involves males in their 60's. Clinical manifestations usually include anemia, kidney disease, hypercalcemia, and bone pains. Neurological manifestations secondary to amyloidosis can occur as well. Diagnosis involves rouleaux formation on a peripheral smear, positive paraproteinemia on urine or serum electrophoresis, skewing of kappa to lambda ratio, and more than $10 \%$ plasma cells on a bone-marrow biopsy. Complications include sepsis, hyperviscosity syndrome, renal insufficiency, and side effects of chemotherapy use. We present to you a case of transfusion-dependent anemia secondary to multiple myeloma leading to the conversion of the blood group from $\mathrm{AB}$ positive to $\mathrm{O}$ positive subtype. Multiple myeloma makes up to $10 \%$ of all hematological malignancies [1,2]. Three percent of the population above the age of 50 have monoclonal gammopathy of undetermined significance (MGUS) that can further turn into a malignancy at a rate of approximately $1 \%$ per year $[3,4]$. Blood group antigens adhere to the red blood cell membrane and do not change throughout an individual's lifetime. Change of blood group type in multiple myeloma is a rare occurrence.

Review began 09/23/2020 Review ended 09/25/2020 Published 09/25/2020

\section{○ Copyright 2020}

Waleed et al. This is an open access article distributed under the terms of the Creative Commons Attribution License CC-BY 4.0., which permits unrestricted use, distribution, and reproduction in any medium, provided the original author and source are credited.

\section{Case Presentation}

A 59-year-old male with a past medical history of multiple myeloma (MM) presented to the emergency department with shortness of breath, fatigue, and palpitations for about two weeks. These symptoms were progressive. They improved at rest and worsened during walking. The patient denied fever, mucosal bleeding, or blurred vision. A review of systems was unremarkable. He was diagnosed with MM two years ago using a bone-marrow biopsy which showed more than $65 \%$ plasma cells. Fluorescence in situ hybridization (FISH) analysis revealed hypodiploidy, i.e. $\mathrm{t}(11 ; 14)$ translocation. His current medications were thalidomide, dexamethasone, bortezomib, and alendronate. The patient also received 26 units of the packed red blood cell concentrate in the past eight months due to recurrent severe anemia. Regarding his social history, the patient was married with three children. He was a nonsmoker and nonalcoholic. On examination, the patient was oriented to time, place, and person. Conjunctivae were markedly pale and mucous membranes were dry. The cardiovascular exam was positive for hyperdynamic circulation and positive S3 sound. Lungs were clear bilaterally. Bowel sounds were hypoactive. The tip of the liver was palpated three fingerbreadths below the costal margin and splenomegaly was present. The patient was crossmatched and started on $\mathrm{O}$ negative packed red blood cells and conservative fluid resuscitation. Chelation with deferoxamine was initiated later as ferritin levels were greater than $1,000 \mathrm{ng} / \mathrm{mL}$ leading to secondary hemochromatosis. After eight days of chelation therapy, his ferritin levels decreased to $210 \mathrm{ng} / \mathrm{mL}$. The rest of the blood results, electrolytes, electrocardiogram, and chest X-Ray were normal ruling out cardiovascular or respiratory causes of dyspnea and palpitations. His complete blood picture, renal, and liver function tests are shown in Table 1 and Table 2. 


\section{Cureus}

\begin{tabular}{|c|c|c|}
\hline & Values & Normal Values \\
\hline Hemoglobin & $7.5 \mathrm{~g} / \mathrm{dl}$ & $11-18 \mathrm{~g} / \mathrm{dl}$ \\
\hline White blood cells & $4000 / \mathrm{uL}$ & $4500 / \mathrm{uL}$ \\
\hline Mean corpuscular volume & $70 \mathrm{fL}$ & 80-99 fL \\
\hline Haematocrit & $22 \%$ & $35-60 \%$ \\
\hline Total iron-binding capacity & $200 \mathrm{ug} / \mathrm{dl}$ & $250-$ \\
\hline
\end{tabular}

TABLE 1: Complete blood picture

\begin{tabular}{|c|c|c|}
\hline & Values & Normal values \\
\hline Alanine transferase & $19 \mathrm{U} / \mathrm{L}$ & $10-50 \mathrm{U} / \mathrm{L}$ \\
\hline Urea & 119 mg/dL & $10-50 \mathrm{mg} / \mathrm{dL}$ \\
\hline Creatine & $1.9 \mathrm{mg} / \mathrm{dL}$ & 0.4-1.4 mg/dL \\
\hline Alkaline phosphatase & 122 U/L & $80-360 \mathrm{U} / \mathrm{L}$ \\
\hline Total bilirubin & $0.1 \mathrm{mg} / \mathrm{dL}$ & $0.3-1.3$ mg/dL \\
\hline Uric acid & $8.6 \mathrm{mg} / \mathrm{dL}$ & 3.0-8.0 mg/dL \\
\hline
\end{tabular}

TABLE 2: Renal and liver function tests

His serum protein electrophoresis showed a sharp well-defined peak in the gamma region, consistent with a monoclonal gammopathy. The results of serum protein electrophoresis are shown in Table 3.

\begin{tabular}{|c|c|c|}
\hline & Current result Units:g/dL & Normal range Units:g/dL \\
\hline Total protein & 14.7 & \\
\hline Albumin & 4.9 & $6.4-8.3$ \\
\hline Alpha 1 & 0.2 & $3.2-5.5$ \\
\hline Alpha 2 & 0.9 & $0.4-1.2$ \\
\hline Beta & 1.0 & $0.5-1.1$ \\
\hline Gamma & 7.5 & $0.5-1.6$ \\
\hline Alpha/Gamma Ratio & 0.5 & $1.2-1.7$ \\
\hline Kappa light chain & 135 & $6.2-13.5$ \\
\hline Lambda light chain & 0.8 & $3.1-7.2$ \\
\hline
\end{tabular}

TABLE 3: Serum protein electrophoresis

\section{Discussion}

Multiple myeloma accounts for 10-20\% of all hematological malignancies [5]. It has an annual incidence of 6/100000 in Western countries [6]. The most common hematological malignancy is Hodgkin lymphoma and the second is multiple myeloma. Multiple myeloma occurs more frequently in males. The median age of patients at diagnosis is 66 years [7]. In various malignancies, especially hematological malignancies, the red blood cell antigen might undergo variation. The most commonly involved antigen undergoing variation is 
the $\mathrm{ABO}$ antigen [8-11]. Acute myelogenous leukemia accounts for the most common cause of $\mathrm{ABO}$ antigen variation. Our case had blood group $A B$ positive since birth; after being diagnosed with multiple myeloma and undergoing multiple blood transfusions, his blood group changed to O positive. A, B, and $\mathrm{H}$ antigens are formed from the same precursor substance. The production of $\mathrm{ABO}$ antigens depends on the functioning of two glycosyltransferases. The first enzyme, $\mathrm{H}$ transferase, adds L-fucose to the terminal galactose of the precursor substance. The $\mathrm{H}$ substance is then acted on by the A or B transferases that add an N-acetyl galactosamine or galactose, respectively. There are two possible mechanisms for the weakening of $\mathrm{ABO}$ antigens in hematopoietic diseases. The first mechanism is the inactivation of $\mathrm{A} / \mathrm{B}$ transferases, and the second is the inactivation of $\mathrm{H}$ transferase [9-15].

\section{Conclusions}

ABO blood group change can occur in multiple myelomas, so the blood group should be checked thoroughly in patients with hematological malignancies. Mismatched blood transfusion can be fatal.

\section{Additional Information \\ Disclosures}

Human subjects: Consent was obtained by all participants in this study. Conflicts of interest: In compliance with the ICMJE uniform disclosure form, all authors declare the following: Payment/services info: All authors have declared that no financial support was received from any organization for the submitted work. Financial relationships: All authors have declared that they have no financial relationships at present or within the previous three years with any organizations that might have an interest in the submitted work. Other relationships: All authors have declared that there are no other relationships or activities that could appear to have influenced the submitted work.

\section{References}

1. Kyle RA, Rajkumar SV: Multiple myeloma. N Engl J Med. 2004, 351:1860-1873. 10.1056/NEJMra041875

2. Goldman L, Ausiello D Rajkumar SV, Kyle RA: Plasma cell disorders. Cecil Textbook of Medicine. 23rd ed. Goldman L, Ausiello D (ed): Saunders, Philadelphia; 2007. 1426-1437. 10.1016/C2009-0-42832-0

3. Kyle RA, Therneau TM, Rajkumar SV, et al.: A long-term study of prognosis of monoclonal gammopathy of undetermined significance. N Engl J Med. 2002, 346:564-569. 10.1056/NEJMoa01133202

4. Kyle RA, Therneau TM, Rajkumar SV, et al.: Prevalence of monoclonal gammopathy of undetermined significance. N Engl J Med. 2006, 354:1362-1369. 10.1056/NEJMoa054494

5. Sergentanis TN, Zagouri F, Tsilimidos G, et al.: Risk factors for multiple myeloma: a systematic review of meta-analyses. Clin Lymphoma Myeloma Leuk. 2015, 15:563-77. 10.1016/j.clml.2015.06.003

6. Jemal A, Siegel R, Xu J, Ward E: Cancer statistics, 2010. CA Can J Clin. 2010, 60:277-300. 10.3322/caac.20073

7. Kyle RA, Gertz MA, Witzig TE, et al.: Review of 1,027 patients with newly diagnosed multiple myeloma . Mayo Clinic Proc. 2003, 78:21-33. 10.4065/78.1.21

8. Kolins J, Holland PV, McGinniss MH: Multiple red cell antigen loss in acute granulocytic leukemia . Cancer. 1978, 42:2248-2253. 10.1002/1097-0142(197811)42:5<2248::AID-CNCR2820420524>3.0.CO;2-T

9. Dobrovic A, O'Keefe D, Sage RE, Batchelder E: Imprinting and loss of ABO antigens in leukemia . Blood. 1993, 82:1684-1685. 10.1182/blood.V82.5.1684.bloodjournal8251684b

10. van der Hart M, van der Veer M, van Loghem JJ: Change of blood group B in a case of leukemia . Vox Sang. 1962, 7:449-453. 10.1159/000464801

11. Hoogstraten B, Rosenfield RE, Wasserman LR: Change of ABO blood type in a patient with leukemia . Transfusion. 1961, 1:32-35. 10.1111/j.1537-2995.1961.tb00008.x

12. Bianco-Miotto T, Hussey DJ, Day TK, O'Keefe DS, Dobrovic A: DNA methylation of the ABO promoter underlies loss of $\mathrm{ABO}$ allelic expression in a significant proportion of leukemic patients. PLoS ONE. 2009, 4:4788. 10.1371/journal.pone.0004788

13. Yoshida A, Kumazaki T, Dave V, Blank J, Dzik WH: Suppressed expression of blood group B antigen and blood group galactosyltransferase in a preleukemic subject. Blood. 1985, 66:990-992. 10.1182/blood.V66.4.990.990

14. Reid ME, Bird GW: Associations between human red cell blood group antigens and disease . Transfus Med Rev. 1990, 4:47-55. 10.1016/S0887-7963(90)70247-7

15. Kuhns WJ, Oliver RT, Watkins WM, Greenwell P: Leukemia-induced alterations of serum glycosyltransferase enzymes. Cancer Res. 1980, 40:268-275. 